logos_i_ethos_2018_1_(47), s. 7-41

DOI: http://dx.doi.org/10.15633/lie.2550

Piotr Duchliński

Akademia Ignatianum w Krakowie

\title{
Ontogeneza pytania "dlaczego"w perspektywie epistemologii genetycznej i jej filozoficzne implikacje
}

\section{Uwagi wstępne}

Pytanie „dlaczego” zrobiło w filozofii, a zwłaszcza w metafizyce, zawrotną karierę ${ }^{1}$. Wielu filozofów uważa, że pytanie to wyraża samą istotę filozofii i jest czymś specyficznym dla uprawiania dyskursu filozoficznego, stanowi także jedno z kryteriów odróżniających filozofię od nauk szczegółowych ${ }^{2}$. Bez wątpienia należeli do nich Arystoteles, Gottfried W. Leibniz czy współcześnie Martin Heidegger. Zdaniem niektórych filozofów w naukach przyrodniczych tego typu pytań się nie stawia, gdyż te nauki ograniczają się tylko do odpowiedzi na pytania „jak”3 . Pytanie „dlaczego” uważa się za kluczowe zwłaszcza dla teistycznie zorientowanej metafizyki ${ }^{4}$. Stale podejmowane są próby jego opracowania i wykazania jego kluczowej roli

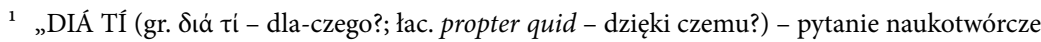
w klasycznej (platońsko-arystotelesowskiej) teorii nauki” (M. A. Krąpiec, DIÁ Tí, http://www.ptta. $\mathrm{pl} / \mathrm{pef} / \mathrm{pdf} / \mathrm{d} /$ diati.pdf [30.01.2018]).

2 Zob. J. Pelc, O poznawczej roli pytań, w: Prace z pragmatyki, semantyki i metodologii semiotyki, red. J. Pelc, Wrocław 1991, s. 191-200.

3 Zob. S. Kamiński, Jak filozofować. Studia z metodologii filozofii klasycznej, Lublin 1989, passim; M. A. Krąpiec, Metafizyka. Zarys teorii bytu, Lublin 1994, passim.

4 Zob. W. Stróżewski, Istnienie i sens, Kraków 1994, passim; W. Stróżewski, O zasadnicze pytanie metafizyki, „Znak” 17 (1965) nr 127, s. 3-23. 
w dyskursie metafizycznym ${ }^{5}$. Wyrugowanie tego pytania z filozofii uważa się za przejaw nonszalancji i niezrozumienia istoty poznania filozoficznego. Wielu teoretyków dostrzega, że zastąpienie pytania „dlaczego” pytaniem „jak” doprowadziło do poważnego kryzysu w filozofii i do wygenerowania postaw minimalistycznych (Kamiński). Wyrugowanie tego pytania wynikało $z$ tendencji do upraktycznienia wiedzy, a tylko odpowiedź na pytanie „jak” daje możliwość poznania faktów i zachodzących między nimi związków. Tomiści uważają, że nadal podstawowe w rozstrzyganiu zagadnień filozoficznych jest podejście metafizyczne, a nie semiotyczne, ponieważ semiotyka odsłania jedynie niektóre aspekty tego pytania, koncentrując uwagę na jego formie logicznej, a pomijając jego związek $\mathrm{z}$ teorią bytu ${ }^{6}$. Właściwe jego postawienie może mieć miejsce tylko przy założeniach realistycznej teorii bytu ${ }^{7}$. W ramach różnych koncepcji filozoficznych pytanie to jest na różne sposoby interpretowane. Dominujące obecnie w Polsce w badaniu tego pytania jest raczej podejście semiotyczne ${ }^{8}$. Filozofowie klasyczni uważają, że pytanie „dlaczego” jest najbardziej podstawowym pytaniem człowieka (Krąpiec) ${ }^{9}$. Już dzieci

5 Zob. J. Wojtysiak, „Dlaczego istnieje raczej coś niż nic?” Analiza problemu w kontekście dyskusji we wspótczesnej filozofii analitycznej, Lublin 2008, passim; J. Wojtysiak, O zasadzie racji dostatecznej, „Roczniki Filozoficzne” 54 (2006) nr 1, s. 179-216; A. Brożek, Pytania i odpowiedzi. Tło filozoficzne, teoria, zastosowania praktyczne, Warszawa 2007, passim.

6 Zob. M. A. Krąpiec, O rozumienie filozofii, Lublin 1995, passim.

7 Zob. A. B. Stępień, Wprowadzenie do metafizyki, Kraków 1964, passim.

8 L. Koj, Analiza pytań I. Problem terminów pierwotnych logiki pytań, w: Studia semiotyczne, wydał i wstępem opatrzył J. Pelc, t. 2, 1971, s. 99-113; L. Koj, Analiza pytań II. Rozważania nad struktura pytań, w: Studia semiotyczne, t. 3, 1973 s. 22-39. Z najnowszych prac warto wspomnieć: A. Wiśniewski, The Posing of Questions: Logical Foundations of Erotetic Inferences, DordrechtBoston-London 1995, passim; A. Brożek, O pytaniach filozoficznych i ich rozstrzygalności, „Studia Philosophiae Christianae" 45 (2009) $\mathrm{nr}$ 1, s. 7-25, O pojęciach rozstrzygalności i nierozstrzygalnоści w świetle teorii pytań, w: Філособсвкі проблеми науки / Filozoficzne problemy nauki, red. A. Brożek, Львів-Warszawa 2008, s. 355-363. W tym obszarze mieszczą się także semiotyczne prace J. Wojtysiaka dotyczące problematyki pytań.

${ }^{9}$ W pewnym sensie niniejszy artykuł jest dyskusją z poglądami autorów tomistycznych. Jest kolejną odsłoną dyskusji miedzy różnymi paradygmatami. Wprawdzie w artykule tym element komparatystki jest mniej wyeksponowany (nie dokonuje się tutaj wprost zestawienia ze sobą różnych podejść teoretycznych do pytania dlaczego), na rzecz bardziej systematycznego podejścia do problemu, ale metodologicznie wpisuje się on w dyskurs klasycznej filozofii aporetycznej, która konfrontuje 
zadają to pytanie spontanicznie pod adresem świata ${ }^{10}$. Człowiek stawia to pytanie przede wszystkim dlatego, że rzeczywistość, której doświadcza, jawi mu się jako niezrozumiała ${ }^{11}$. Wyraża ono podstawową potrzebę poznania i zrozumienia świata, która jak trafnie zdiagnozował Stagiryta, właściwa jest każdemu człowiekowi. Pytanie to gruntuje szereg innych pytań, np. udzielenie odpowiedzi na pytanie „jak” zakłada odpowiedź na pytanie „dlaczego" ${ }^{12}$.

Filozofowie rzadko kiedy podchodzą do analizy pytania „dlaczego” z perspektywy ontogenezy. Uważają, że jest to domena psychologów. Wielu też twierdzi, że filozofia jest autonomiczna w punkcie wyjścia, dlatego nie musi korzystać z danych psychologii, gdyż sama może dojść do nie mniej ważnych ustaleń niż psychologia. To jednak nie oznacza w żadnym wypadku deprecjonowania rezultatów badań psychologicznych. Sami przecież tomiści egzystencjalni mniej lub bardziej świadomie zahaczają o ontogenezę pytań, kiedy twierdzą np., że pytania te spontanicznie są zadawane przez dzieci, że pytań tych nikt ich nie uczy, że to sam świat realny wymusza na dzieciach ich formułowanie. To wszystko są tezy, które dotyczą ontogenezy pytań. Poza tymi stwierdzeniami nie podejmuje się jednak głębiej problematyki ontogenezy pytań

ze sobą różne stanowiska; klasyczne ze współczesnymi, w celu odkrywania nowych sytuacji problemowych i proponowania nowych, kontrowersyjnych, bo inne w przypadku filozofii być nie mogą, rozstrzygnięć.

10 „Pytanie «dlaczego» jest więc naczelnym, pierwotnym pytaniem-kluczem, otwierającym pole racjonalności płynące ze zrozumienia bytu i bytowych relacji, które jako realne są możliwe do odczytania jedynie przez intelekt, a nie przez zmysły. Pierwotna teoria naukowego poznania, spełnianego przez ludzki rozum, jest otwarta na odczytanie i rozumienie całego pola bytowego w granicach usuwania z tego pola absurdu, czyli sprzeczności, która uśmierca akty poznania” (M. A. Krąpiec, DIÁ TÍ, dz. cyt.). Zwrócę tylko uwagę na to, że autor ten w swoich pracach bardzo często posługuje się metaforą „odczytania” struktury bytu.

11 Zob. S. Szuman, Rozwój pytań dziecka. Badania nad rozwojem umysłowości dziecka na tle jego pytań, w: Studia nad rozwojem psychicznym dziecka, wybór i opracowanie M. Przetacznikowa, G. Makiełło-Jarża, Warszawa 1985, s. 274-321; S. Szuman, Rozwój pytań dziecka. Badania nad rozwojem umysłowości dziecka na tle jego pytań, Warszawa 1939, passim. Nowsze ujęcie, z którego korzystałem, to: Psycholingwistyka, red. J. B. Gleason, B. N. Ratner, tłum. J. Bobryk, Gdańsk 2005, zwłaszcza wartościowy dla naszych poszukiwań jest rozdział 8.

12 M. A. Krąpiec, Filozofia co wyjaśnia, Lublin 1999, s. 37-38. 
metafizycznych. Filozofowie przejawiają tendencję do koncentrowania się na poznaniu już ukształtowanego podmiotu, mniej interesuje ich genetyczny aspekt poznania, a to nie służy ukazaniu jego integralnego obrazu.

Kwestię ontogenezy pytania „dlaczego” zamierzamy prześledzić w niniejszych analizach, obierając sobie za przewodnika znanego szwajcarskiego psychologa rozwojowego, twórcę epistemologii genetycznej Jeana Piageta ${ }^{13}$. Wydaje się, że wiele jego ustaleń nadal zachowuje swoją ważność teoretyczną. Epistemologia genetyczna, która traktuje ludzkie poznanie jako dynamiczny proces narastania coraz to bardziej skomplikowanych czynności i operacji kognitywnych, korzysta w swoich ustaleniach $\mathrm{z}$ wyników psychologii rozwojowej ${ }^{14}$. Dlatego nie jest dyscypliną metodologicznie autonomiczną. Jest interdyscyplinarna, gdyż w wyjaśnieniu poznania odwołuje się do wielu nauk, ponadto swoje wyniki poddaje kontroli empirycznej ${ }^{15}$. Daleka jest jednak od spekulatywnego podejścia właściwego dla tradycyjnej epistemologii. Dystansuje się także od udzielania ostatecznych odpowiedzi w kwestii czynności i operacji poznawczych. Nawiązując do przełomowych prac Piageta, dokonamy najpierw hermeneutycznej rekonstrukcji ${ }^{16}$ ontogenezy pytania

13 Zob. J. Piaget, Psychologia i epistemologia, tłum. Z. Zakrzewska, Warszawa 1977; J. Piaget, Mowa i myślenie dziecka, tłum. J. Kołudzka, Warszawa 2005; M. Kielar-Turska, Przedmowa, w: Mowa i myślenie dziecka, tłum. J. Kołudzka, Warszawa 2005, passim; J. Piaget, Jak dziecko wyobraża sobie świat, tłum. M. Gawlik, Warszawa 2006. Z opracowań warto odnotować: K. Zamiara, Epistemologia genetyczna Piageta a społeczny rozwój nauki, Warszawa-Poznań 1979; K. Zamiara, Epistemologiczne założenia psychologicznej wizji człowieka, w: Materiały XXVI Zjazdu PTP, Szczecin 1987, red. E. Aranowska, Warszawa 1991, M. Kielar-Turska, Średnie dzieciństwo. Wiek przedszkolny, w: Psychologia rozwoju człowieka. Podręcznik akademicki, red. J. Trempała, Warszawa 2011, passim.

${ }^{14} \mathrm{~W}$ artykule pomijam szczegółową prezentację epistemologii genetycznej, gdyż to znacznie przekroczyłoby ramy wyznaczonych analiz. W tej materii odsyłam do prac metateoretycznych Krystyny Zamiary.

15 J. Piaget, Psychologia i epistemologia, dz. cyt., s. 15-42; K. Zamiara, Obecność myślenia psychologicznego w epistemologii, w: Rozprawy i szkice z filozofii i metodologii nauk, red. J. Such, WarszawaPoznań 1992, s. 38-52.

16 Chodzi tu o analizę hermeneutyczną. Zob. H. H. Krűger, Wprowadzenie $w$ teorie i metody badawcze nauk o wychowaniu, tłum. D. Sztobryn, oprac. B. Śliwerski, Gdańsk 2005, s. 146-147. Zaznaczam, że nie jest to pełna rekonstrukcja ontogenezy. Zwracam uwagę tylko na te aspekty 
"dlaczego", następnie postaramy się sformułować implikacje filozoficzne, które wypływają z tej koncepcji ${ }^{17}$. Czego może nauczyć się od Piageta filozof nastawiony maksymalistycznie do badania rzeczywistości? ${ }^{18}$

\section{Ontogeneza pytań „dlaczego” według Jeana Piageta}

Piaget był psychologiem, którego nie interesowały spekulacje, lecz fakty. Badając rozwój dziecięcej logiki, zawsze starał się opierać na faktach, której mniej lub bardziej potwierdzałyby jego hipotezy. Obserwując dzieci w różnym okresie życia, osobiście lub też przy pomocy swoich współpracowników, sporządzał szereg zapisów różnych typów pytań, które próbował poklasyfikować, biorąc pod uwagę tak kryteria formalne, jak i materialne (treściowe) ${ }^{19}$. Jako priorytetowe uznawał kryterium materialne. To kryterium stosuje także przy klasyfikacji pytań „dlaczego", $\mathrm{z}$ tego względu, że po samej ich formie nie jesteśmy w stanie dociec, o jaki typ przyczyny pyta dziecko. Na podstawie tego kryterium stwierdza, że „można przyjąć trzy wielkie grupy pytań «dlaczego?» u dzieci: «dlaczego?» odnoszące się do wyjaśnienia przyczynowego (łącznie $\mathrm{z}$ wyjaśnieniem finalistycznym), do motywacji i do uzasadnienia, w obrębie których da się jeszcze rozróżnić pewną ilość odcieni. Począwszy od pewnego wieku (7-8 lat i więcej) trzeba by odróżnić dalej pytania «dlaczego?» odnoszące się do uzasadnienia logicznego"20. Te ostatnie pojawiają się najpóźniej w ontogenezie dziecka. Pojęcie „wyjaśnienia” odnosi się albo do wyjaśnienia logicznego, które polega na dedukcyjnym powiązaniu określonych zdań, albo do wyjaśnienia, które bierze pod uwage przyczyny sprawcze, finalne oraz motywy psychologiczne.

koncepcji szwajcarskiego psychologa, które są potrzebne do przeprowadzenia dyskusji nad statusem i rolą pytania "dlaczego".

17 Implikacji tych nie należy traktować jako stwierdzeń koniecznych, lecz raczej jako hipotezy, które oczywiście mogą być odrzucone przy innych założeniach.

18 Wyprowadzone implikacje będą zatem dotyczyły nie tylko struktury poznania, ale też struktury teorii filozoficznej. Dlatego wszystkie one mają charakter metateoretyczny.

19 J. Piaget, Mowa i myślenie dziecka, dz. cyt., s. 150-155.

20 J. Piaget, Mowa i myślenie dziecka, dz. cyt., s. 153. 
Wyróżnia się też pytania „dlaczego", dotyczące różnego rodzaju reguł oraz norm społecznych, które dziecko zastaje w toku socjalizacji. Są one pokrewne pytaniom dotyczącym motywacji. Dziecko bardzo często pyta albo o motyw akceptacji jakiejś reguły lub normy, albo też w wieku późniejszym o racje logiczne uznawania danej reguły lub normy za prawomocną ${ }^{21}$. Ze względu jednak na wieloznaczność rozumienia przyczyny przez dzieci trzeba przy klasyfikacji pytań brać pod uwagę kryterium treściowe zwracające uwagę na przedmioty, o które dziecko zapytuje. Piaget nie bierze też pod uwagę pytań dziecka właściwych dla stadium egocentrycznego. Uważa, że są to raczej pseudopytania. W postawie tej dziecko stawia pytania samo dla siebie, nawet jeśli czyni to w kontekście osób dorosłych, nie domaga się od nich żadnej odpowiedzi. Dotyczy to także "dialogów" rozgrywanych w postawie egocentrycznej między rówieśnikami. Również w tym kontekście stawiane pytania nie zakładają żadnej intencji poszukiwania informacji ze strony innych dzieci. Zasadniczo pierwszy krokiem uczenia się pytań w ontogenezie jest ich bierne powtarzanie za dorosłymi. Dziecko naśladuje dorosłych, nie rozumiejąc jeszcze znaczenia wypowiadanych przez nich zdań pytajnych. Dziecko, które jest egocentrykiem, nie potrafi konfrontować swoich myśli i pytań z innymi ludźmi, nie potrafi też zobiektywizować swojego myślenia, które jest zawsze związane z depersonalizacją i próbą przyjęcia punktu widzenia innych ${ }^{22}$.

Ontogeneza dziecięcych pytan „dlaczego" rozpoczyna się około 3 roku życia. Do co najmniej 7 roku życia można mówić o czymś w rodzaju hipertrofii pytań zadawanych dorosłym przez dzieci. Pytanie „dlaczego” nie jest jednak pierwotnym pytaniem dziecka. Bardziej podstawowymi pytaniami, które formułuje dziecko, są pytania o to gdzie znajdują się przedmioty, lub też o ich nazwę. Dziecko bardzo często pyta „co to jest”, domagając się od dorosłego podania nazwy przedmiotu. Pierwsze pytania „dlaczego" stawiane przez dzieci wyrastają bardziej z niepokoju

21 Zob. J. Piaget, Mowa i myślenie dziecka, dz. cyt., s. 154.

22 Zob. J. Piaget, Mowa i myślenie dziecka, dz. cyt., s. 206. 
i zaciekawienia emocjonalnego niż intelektualnego ${ }^{23}$. Od tej uczuciowej ciekawości świata dziecko stopniowo przechodzi do ciekawości intelektualnej, co wyraża się w formułowaniu coraz bardziej wyrafinowanych pytań. Zadawanie pytań „dlaczego”, które ma miejsce około 3 roku życia dziecka powiązane jest $\mathrm{z}$ konstytuowaniem się różnych poziomów realności. Piaget wyjaśnia, że chodzi tu o to, że „mniej więcej do 3 roku życia można powiedzieć, że realne jest po prostu to, co jest pożądane. Istnieje wprawdzie od 1 albo 2 roku życia pewne «tak» $\mathrm{i}$ «nie», rzeczy realne i nierealne, ale bez żadnych odcieni. Natomiast około 3 roku życia dziecko odróżnia rzeczy urojone od rzeczywistych" ${ }^{24}$. Pojawienie się pytań „dlaczego" wiąże się zatem z nowym doświadczeniem rzeczywistości przez dziecko. Do 3 roku życia dziecko doświadcza zgodności swoich pragnień i życzeń z rzeczywistością. Potem następuje stopniowe doświadczenie oporu ze strony świata. Dziecko doświadcza, że jego potrzeby i życzenia nie zgadzają się z rzeczywistością rzeczy i dorosłych. Stopniowo zaczyna odróżniać świat bezpośrednio dany w percepcji oraz coś, co poprzedza wszystkie wydarzenia, co jest ich stałym podłożem. Tym czymś jest intencja. Pojawia się ona na skutek oporu, jakiego doświadcza dziecko ze strony rzeczywistości ${ }^{25}$. Dziecko zaczyna przypisywać wszystkim zjawiskom i wydarzeniom intencje, celowość, posiadanie wewnętrznych sił, które oddziałują na nie. W ten sposób świat dziecka zaludnia się intencjami przypisywanymi rzeczom oraz innym osobom ${ }^{26}$. „Intencje właśnie, przypisywane ludziom i rzeczom, dają z czasem początek typom pytań odpowiadającym głównym kategoriom myślenia dziecka. Kategorie te są zatem pochodzenia intencjonalnego, to znaczy rodzą się z uświadomienia sobie czynności psychicznych odnoszących się do intencji, a nie do zwykłego stwierdzenia świata w percepcji. Po za tym do tych kategorii intencjonalnych włączają się następnie kategorie chronologicznie wcześniejsze (nazwa, miejsce), ażeby stanowić z nimi

23 Zob. J. Piaget, Mowa i myślenie dziecka, dz. cyt., s. 152.

24 J. Piaget, Mowa i myślenie dziecka, dz. cyt., s. 202.

25 Zob. J. Piaget, Mowa i myślenie dziecka, dz. cyt., s. 204.

26 Zob. J. Piaget, Mowa i myślenie dziecka, dz. cyt., s. 202-203. 
jedną całość" 27 . Stąd też pierwsze pytania „dlaczego” formułowane przez dzieci dotyczą przede wszystkim intencji ukrytych w czynności albo w zdarzeniu. Pierwsze dziecięce „dlaczego” odnosi się zatem do ludzkich czynności.

Pytania „dlaczego” odnoszą się do różnych typów przyczynowości. Zanim dziecko posiądzie zdolność posługiwania się pojęciem przyczyny, samo traktuje siebie jako przyczynę inicjującą wiele działań. Oczywiście nie zdaje sobie z tego sprawy, co upoważnia do mówienia o przyczynowości niezależnie od stopnia uświadomienia ${ }^{28}$. Uświadomienie stosunków przyczynowych kształtuje się stopniowo wraz z rozwojem czynności i operacji umysłowych i prowadzi do wyróżnienia różnych typów przyczynowości, takich jak: przyczynowość animistyczna, finalistyczna, mechaniczna, dynamiczna itp. Przyczynowość nie pochodzi zatem od samych spostrzeżeń. Nie jest wynikiem jakiegoś prostego uogólnienia abstrakcyjnego. Jest kategorią dynamiczną, która przechodzi swoje stopnie uwyraźnienia w trakcie ontogenezy, co prowadzi do tego, że niektóre typy przyczynowości ustępują innym, np. przyczynowość animistyczna ustępuje stopniowo miejsca przyczynowości mechanicznej opartej na przestrzennej styczności przedmiotów.

Pierwsze pytania „dlaczego” dotyczące przyczynowości nie odnoszą się jednak do przyczynowości mechanicznej. Dziecko nie operuje na tym etapie przyczynowością, która polega na przestrzennej styczności przedmiotów. Stawiając pytanie „dlaczego”, poszukuje ukrytych za przedmiotami i zdarzeniami sił oraz intencji. Większość pytań formułowanych jest pod adresem bytów ożywionych, statystycznie mniej w stosunku do przedmiotów martwych. Dla dziecka, które przypisuje przedmiotom i osobom intencje oraz siły, świat jest pozbawiony przypadku. Jest pewną całością ściśle ze sobą powiązanych wydarzeń i sytuacji. Wszystko dzieje się wedle pewnej konieczności. Jak pisze Piaget, „świat, w którym nie ma przypadkowości, jest światem dużo mniej

27 J. Piaget, Mowa i myślenie dziecka, dz. cyt., s. 203.

28 Zob. J. Piaget, Mowa i myślenie dziecka, dz. cyt., s. 200. 
mechanicznym, o wiele bardziej antropomorficznym od naszego"29. Agnostycyzm życia codziennego ${ }^{30}$ powiązany z wprowadzeniem kategorii przypadku pojawia się później, kiedy dziecko odkrywa fakt śmierci. Dla człowieka dorosłego, który posługuje się pojęciem przyczynowości mechanicznej, w świecie obecny jest przypadek polegający na krzyżowaniu się niezależnych względem sobie łańcuchów przyczynowych. Między 7 a 8 rokiem życia dziecko nie operuje tego typu pojęciem przyczynowości. Przyczynowość ma charakter celowy i dotyczy bardziej motywacji psychologicznej. Nie ma charakteru przestrzennego stykania się dwóch przedmiotów. Piaget uważa nawet, że na tym etapie mamy do czynienia nie tyle z przyczynowością, ile raczej z przedprzyczynowością. Twierdzi, że „oznaczymy nazwą przedprzyczynowości ten związek pierwotny, kiedy przyczynowość ma jeszcze charakter motywacji niejako psychologicznej. Jedną z form tej przedprzyczynowości jest wyjaśnienie antropomorficzne przyrody: przyczyna zjawisk zlewa się w tym wypadku z intencją Stwórcy albo z intencją ludzi, którzy są wytwórcami gór lub rzek. Ale, jeśli nawet żadna intencja nie przejawia się w tej formie antropomorficznej, racja, która dziecko usiłuje dać zjawisku, jest dużo bliższa jakieś racji utylitarnej albo motywu aniżeli kontaktu przestrzennego" ${ }^{31}$. Owa przedprzyczynowość jest uwarunkowana „realizmem intelektualnym” dziecka. Dziecko ma tendencję do stałego uzupełniania myślami tego, co widzi. Rzeczywistość, której doświadcza, jest o wiele bardziej przez nie skonstruowana, niż dostarczona przez czystą obserwację. W tym znaczeniu realizm dziecka nie jest realizmem wzrokowym, lecz właśnie intelektualnym. Jeśli będziemy obserwować dziecko poniżej 7 roku życia, to „uderzy nas fakt, jak bardzo jego widzenie jest zniekształcone przez jego myśl”32. Dlatego dziecko nie poszukuje wyjaśnień opartych na przyczynowości mechanicznej (styczność prze-

29 J. Piaget, Mowa i myślenie dziecka, dz. cyt., s. 159.

30 Chodzi tutaj o pewną postawę, która pojawia się w momencie, kiedy podmiot poznający zdaje sobie sprawę, że w świecie występuje przypadek, że nie wszystko jest celowo uporządkowane, że niektórych zjawisk nie jesteśmy w stanie poznać i przewidzieć ich zachodzenia.

31 J. Piaget, Mowa i myślenie dziecka, dz. cyt., s. 164.

32 J. Piaget, Mowa i myślenie dziecka, dz. cyt., s. 165. 
strzenna), lecz zgodnie z realizmem intelektualnym doszukuje się w zjawiskach i wydarzeniach motywów lub intencji (finalizm). Wyjaśnienia podawane przez dziecko nie mają charakteru dedukcji logicznej. „Dla dziecka fakt pociągający za sobą inny fakt, motyw pociągający za sobą czynność i myśl pociągająca za sobą inną myśl, są jeszcze jednym i tym samym, lub - jeśli kto woli - świat fizyczny i świat intelektualny albo psychiczny są jeszcze ze sobą przemieszane"33. W tym okresie dziecko przejawia też wszechobejmującą tendencję do uzasadnienia wszystkiego. Tym różni się od dorosłych, którzy po pierwsze akceptują istnienie przypadku, po drugie uważają, że pewne rzeczy i wydarzenia nie mogą być wyjaśnione. Dziecko odrzuca to, co jest w doświadczeniu dane jako przypadkowe, niepowiązane ze sobą, po prostu chaotyczne. W postawie realizmu intelektualnego „pojęcie czegoś «danego» nie umyka zupełnie myśleniu dziecka, które wzbrania się uznawać w doświadczeniu przypadkowe zbiegi okoliczności po prostu „dane” bez dalszego uzasadnienia. Jest przeto u dziecka skłonność do uzasadnienia za wszelką cenę, przekonanie to samorzutne, że wszystko wiąże się ze wszystkim, i że można wyjaśnić wszystko przez wszystko. Przy tego rodzaju postawie umysłu dziecko musi posługiwać się pojęciem przyczynowości innej niż mechaniczna, takim, które służy dobrze zarówno do uzasadnienia, jak i do wyjaśnienia, i stąd dochodzimy do pojęcia przedprzyczynowości”34.

Skłonność do uzasadnienia wszystkiego ze wszystkim opiera się na synkretyzmie. Poniżej 7 roku życia percepcja i inteligencja dziecka są zasadniczo synkretyczne. Realizm intelektualny i synkretyzm w postrzeganiu i myśleniu są ze sobą powiązane ${ }^{35}$. Synkretyzm w myśleniu (inteligencja werbalna) i spostrzeganiu (inteligencja percepcyjna) dziecka polega na odwoływaniu się do ogólnych schematów analogicznych o charakterze percepcyjnym i wyobrażeniowym. Przy zastosowaniu tych schematów dokonuje się rozumienie zróżnicowanych części. Schematy mają przeważnie charakter nieokreślony i mało analityczny, co ułatwia

\footnotetext{
33 J. Piaget, Mowa i myślenie dziecka, dz. cyt., s. 166.

34 J. Piaget, Mowa i myślenie dziecka, dz. cyt., s. 167.

35 Zob. J. Piaget, Mowa i myślenie dziecka, dz. cyt., s. 167.
} 
ich wiązanie w pewne mniej lub bardziej koherentne całości. Postrzeganie dziecka jest synkretyczne, całościowe i nie koncentruje się na dekodowaniu szczegółów. To sprawia, że dziecko nie dostrzega niuansów koniecznych np. do uchwycenia przestrzennej styczności przedmiotów, co właściwe jest dla przyczynowości mechanicznej. Dziecko nie potrafi dostosować się do szczegółów. Spostrzeganie synkretyczne, jak twierdzi Piaget, niejako zniewala dziecko do powiązania rzeczy z samą myślą. Powiązanie wszystkiego ze wszystkim ma dla niego (stadium 5-6 lat) charakter konieczny. Poczucie konieczności wyprzedza zatem wszelkie wyjaśnienie. Dlatego równie dobrze odpowiedź na zadawane przez dzieci pytania „dlaczego?” mogłaby brzmieć „tak musi być”. Piaget, obserwując dzieci i katalogując ich pytania, zauważa jednak, że „dziecko miesza zresztą na ogół konieczność ludzką (moralną, społeczną, to co wypada) oraz konieczność fizyczną (pojęcie prawa bardzo długo zresztą nosiło ślady tego pochodzenia). Dlatego też w bardzo wielu dziecięcych «dlaczego» chodzi tylko o uzyskanie tego poczucia konieczności [...]. Łatwo zrozumieć, w jaki sposób ten typ wyjaśnienia jest związany z przedprzyczynowością, która właśnie wynika z pomieszania świata fizycznego albo umysłowego, czyli świata konieczności moralnej i logicznej ze światem fizycznym, czyli światem konieczności mechanicznej"36.

Piaget zwraca także uwagę, że myślenie w kategoriach przedprzyczynowości i realizmu intelektualnego jest uwarunkowane przez pierwotny egocentryzm. To właśnie on długo uniemożliwia wejście dziecku na poziom myślenia obiektywnego (intersubiektywnego), które zawsze jest związane z konfrontowaniem myśli z innymi mającym swój początek w zadawaniu pytań typu: „, co to jest?, , gdzie to jest?”, „dlaczego tak jest?”. Im bardziej dziecko koncentruje się na swoim Ja, tym mniej zdolne jest do uwolnienia się od przekonań animistycznych, od traktowania wszystkich rzeczy i zjawisk w kategoriach intencji i ukrytych sił, które wpływają na ich pojawianie się. To właśnie ów egocentryzm „pozostaje w ścisłym związku z niezdolnością do ścisłego wyjaśnienia przyczynowego i ścisłego uzasadnienia logicznego. Rozumiemy na tej podstawie, dlaczego

36 J. Piaget, Mowa i myślenie dziecka, dz. cyt., s. 168. 
myślenie dziecka unosi się między tymi dwiema zbieżnymi drogami i jest zawsze oddalone zarówno od jednej, jak i od drugiej. Stąd wynikają zjawiska przedprzyczynowości i realizmu intelektualnego, które świadczą o owej pozycji pośredniej. Stąd też pochodzi skłonność dzieci do uzasadnienia za wszelką cenę albo wiązania wszystkiego ze wszystkim" ${ }^{37}$.

W okresie między 3 a 7 rokiem życia dziecko właściwie pyta o wszystko. Przyjmując postawę realizmu intelektualnego, myśli i postrzega synkretycznie, przez co ujmuje wszystko, czego doświadcza, w kategorie przyczynowości animistycznej, artyficjalnej oraz psychologicznej. Stopniowo jednak w toku ontogenezy zanika pojęcie przedprzyczynowości. W zadawanych przez dzieci (od 7-8 lat) pytaniach coraz częściej pojawia się czyste pojęcie przyczynowości odnoszące się do przyczynowości mechanicznej. Dziecko coraz częściej zwraca uwagę na szczegóły różnych rzeczy oraz uczy się dostrzegać zachodzącą między nimi styczność przestrzenną. Względna liczebność pytań „dlaczego” spada, ustępując coraz częściej miejsca pojawiającym się pytaniom dotyczącym realności i historii oraz wyjaśnienia logicznego. „W uzasadnieniu logicznym myśl dochodzi do świadomości swojej niezależności, możliwych błędów i umownych założeń: stara się teraz o uzasadnienie nie rzeczy jako takich, ale swoich własnych sądów. Tego rodzaju przejście dokonuje się w rozwoju psychicznym późno" ${ }^{38}$. Prawdopodobnie ma miejsce między około 7-8 roku życia, co związane jest ze stopniowym zanikiem myślenia animistycznego. Zanikanie liczby pytań „dlaczego” spowodowane jest przez to, że dziecko stawia zupełnie inne pytania, które mają za zadanie uzupełnić jego wiedzę. Odpowiedzi na pytania „dlaczego” dostarczają przeważnie wiedzy ogólnej. Tymczasem dziecko przejawia stałą i niepohamowaną potrzebę uzyskiwania wiedzy szczegółowej, spełniającej wymogi uzasadnienia logicznego i koherencji. Obok pytań dotyczących realności wydarzeń oraz ich historii, dziecko stawia także pytania dotyczące reguł, które coraz bardziej wyzwolone są spod presji idei antropomorficznych i psychologicznych. Odnośnie do reguł

37 J. Piaget, Mowa i myślenie dziecka, dz. cyt., s. 206.

38 J. Piaget, Mowa i myślenie dziecka, dz. cyt., s. 173. 
dopytuje o logiczne uzasadnienie ich obowiązywalności. Dziecko stawia też coraz więcej pytań odnoszących się do liczenia i klasyfikacji otaczających je przedmiotów. Zapytuje nie tylko o podanie nazwy przedmiotu, lecz także o jej definicję, która służy do jego zrozumienia. Pytania o reguły, nazwy oraz definicje mają, zdaniem szwajcarskiego psychologa, charakter pytań normatywnych ${ }^{39}$. Natomiast widoczny spadek pytań dotyczących przedprzyczynowości jest związany ze stopniowym zanikaniem myślenia egocentrycznego. Egocentryzm, który bardziej jest posłuszny logice osobistych zachcianek i pragnień, długo może zniewalać dziecko, stanowiąc bezpośrednią przeszkodę w uzyskaniu systematyzacji logicznej i myślenia zdepersonalizowanego ${ }^{40}$.

Jednym ze sposobów, przy pomocy którego można zweryfikować spadek myślenia u dzieci w kategoriach przedprzyczynowości, jest zadawanie dziecku pewnych pytań, formułowanych przez nie przed okresem 7 roku życia. Kiedy dziecku w wieku powyżej 7 lat zadajemy pytania, które stawiało ono na etapie 6-7 roku życia, wyraża zdziwienie, czasem też zakłopotanie. Wówczas bardzo często prostuje dorosłego, że pytań takich się nie stawia, bo są one po prostu bezsensowne, lub też udziela na nie odpowiedzi, które biorą pod uwagę przyczynowość mechaniczną albo uzasadnienie logiczne odwołujące się do określnych związków inferencyjnych między sądami. Piaget skrupulatnie zapisywał i systematyzował według kryterium materialnego pytania dziecka o imieniu Del. Stwierdził, że pojęcie przedprzyczynowości, którym się posługiwało, stawało się coraz bardziej zróżnicowane, co było związane ze stopniowym zastępowaniem przyczynowości mechanicznej na rzecz poszukiwania uzasadnień logicznych. Zaobserwował też, że ustępowanie przedprzyczynowości wiąże się z zanikaniem myślenia antropomorficznego i artyficjalistycznego. Pisał tak: „Występuje więc wyraźna niezgodność między pytaniami Del a sposobem, w jaki sam na nie odpowiadał w kilka miesięcy później, co zdaje się wskazywać, że po części porzucił on już wyjaśnienia przedprzyczynowe. Istotnie pytania były stawiane tak, jakby wyjaśnienie

39 Zob. J. Piaget, Mowa i myślenie dziecka, dz. cyt., s. 183-190.

40 Zob. J. Piaget, Mowa i myślenie dziecka, dz. cyt., s. 206. 
przedprzyczynowe było możliwe, to znaczy jakby wszystko mogło być uzasadnione w przyrodzie, jakby wszytko było ożywiane intencjami, tak że poszukiwana przyczyna zjawisk utożsamia się z motywem natury psychologicznej albo z racjami natury moralnej"41. Odpowiedzi udzielane przez Del nie brały pod uwagę pojęcia przedprzyczynowości. Wiązało się to $\mathrm{z}$ tym, że pojawiały się $\mathrm{w}$ jego umyśle poprawne odróżnienia między różnymi typami przyczynowych związków zachodzących między przedmiotami. Nie znaczy to jednak, że w tym okresie czasu dziecko uzyskuje już czyste pojęcie przyczynowości mechanicznej czy też uzasadnienia logicznego. Jeszcze przez długi czas ontogenezy uzasadnienie to będzie wymieszane z uzasadnieniem psychologicznym. Dopiero w wieku późniejszym (od 11-12 lat) wyjaśnianie przyczynowe i uzasadnienie logiczne stają się „czyste”, czyli pozbawione domieszki poszukiwania motywacji psychologicznej.

Z pytaniami „dlaczego”, podkreśla Piaget, związane są trzy funkcje: eksplikatywna, implikacyjna i mieszana ${ }^{42}$. Funkcje te mają charakter dynamiczny. Początkowo występują w pewnym stanie niezróżnicowania. Dopiero $w$ trakcie ontogenezy stopniowo się rozwijają i usamodzielniają, przechodząc $\mathrm{w}$ funkcje powiązane $\mathrm{z}$ coraz bardziej złożonymi czynnościami i odwracalnymi operacjami kognitywnymi. Funkcja eksplikatywna jest w początkach ontogenezy najbardziej dominująca. Wynika z potrzeby, której dziecko doznaje w momencie, gdy uświadamia sobie istnienie intencji pojawiającej się pod wpływem oporu spowodowanego rozbieżnością pragnień i rzeczy. Wówczas odczuwa ono potrzebę przypisywania tych intencji innym przedmiotom oraz osobom, których oporu doświadcza. Funkcja ta ma dwa bieguny: wyjaśnienie psychologiczne i wyjaśnienie materialne. Bieguny te w początkowym okresie ontogenezy nakładają się na siebie. Dopiero w późniejszych etapach coraz bardziej się rozchodzą ${ }^{43}$. Funkcja ta zwraca się ku światu zewnętrznemu. Nakierowana jest na realizm, czas, miejsce oraz przyczynowość.

41 Zob. J. Piaget, Mowa i myślenie dziecka, dz. cyt., s. 197.

42 Zob. J. Piaget, Mowa i myślenie dziecka, dz. cyt., s. 203-204.

43 Zob. J. Piaget, Mowa i myślenie dziecka, dz. cyt., s. 204. 
Pierwotnie bowiem funkcja implikacyjna powstaje w wyniku poszukiwania przez dziecko ukrytych w przedmiotach intencji i sił. Również i ona ma dwa bieguny; pierwszy jest psychologiczny, drugi natomiast dotyczy nazw, klasyfikacji, czyli uzasadnienia logicznego. Kierunek funkcji implikacyjnej zwraca się zatem nie do rzeczy, ale do intencji, motywów oraz idei. W toku ontogenezy funkcja ta jakby się specjalizuje i zaczyna odgrywać coraz większą rolę w myśleniu, które stopniowo opuszcza etap przedprzyczynowości. W pełnym i rozwiniętym stopniu funkcja implikacyjna właściwa jest dla uzasadnienia logicznego. Wówczas zwraca się ku klasyfikacji, nazywaniu, uchwytywaniu określonych stosunków logicznych zachodzących między sądami. Pytanie o nazwy i definicje wiąże się z funkcję implikacyjną. Coraz mniej dotyczy rzeczy realnych (funkcja eksplikacyjna), a coraz bardziej pojęć i definicji, które są od nich niezależne. W uzasadnieniu logicznym chodzi bowiem o koncentrację na związkach między zdaniami, a nie rzeczami. Na tym etapie dziecko uchwytuje niezależność myśli i rzeczy. Funkcja eksplikatywna i implikacyjna może także występować w funkcji mieszanej, wówczas zwraca się ku motywacji czynów oraz uzasadnieniu reguł i norm, z którymi dziecko styka się w trakcie rozwoju społecznego. Razem z rozwojem i różnicowaniem się tych funkcji różnicują się również treściowo formułowane przez dziecka pytania, na co zwraca uwagę paradoksalny fakt, że „myśl dziecka jest jednakowo daleka od operowania ścisłym wyjaśnieniem przyczynowym (eksplikacja) jak i implikacja, czyli uzasadnieniem logicznym we właściwym znaczeniu. Cały mechanizm pytań dziecięcych, które poznaliśmy, mieści się w tym zasadniczym fakcie" ${ }^{\text {"44 }}$.

\section{Implikacje filozoficzne ontogenezy pytania „dlaczego”}

(1) Ontogeneza pytania „dlaczego" dostarcza szeregu interesujących implikacji, które z jednej strony potwierdzają, z drugiej zaś kwestionują szereg tez głoszonych np. przez metafizyków tomistycznych. Warto zwrócić uwagę na kilka kwestii metateoretycznych, które z tym

44 J. Piaget, Mowa i myślenie dziecka, dz. cyt., s. 205. 
są związane. Na samym początku trzeba pamiętać, że z samej ontogenezy pytań wprost nie wynikają żadne jednoznaczne implikacje filozoficzne. Jeśli o nich mówimy, to tylko jako o pewnych konsekwencjach interpretacyjnych ${ }^{45}$. A każda $\mathrm{z}$ tych interpretacji jest zawsze zrelatywizowana do określnej hermeneutyki filozoficznej ${ }^{46}$. Stąd też wyprowadzone implikacje siłą rzeczy nie będą podzielane przez wielu filozofów, zwłaszcza tych, którzy bronią autonomii epistemologicznej filozofii względem nauk empirycznych, i w punkcie wyjścia wygłaszają stwierdzenia konieczne, dystansując się od jakichkolwiek hipotez ${ }^{47}$. Bez wątpienia uprawiana przez Piageta epistemologia genetyczna jest nauką mocno osadzoną w empirycznych danych psychologii rozwojowej ${ }^{48}$. Trzeba jednak pamiętać o tym, że cel badań Piageta był epistemologiczny, chodziło

45 Zob. J. Woleński, W stronę logiki, Kraków 1996, passim; J. Turek, Filozoficzne interpretacje faktów naukowych, Lublin 2009, passim; J. Turek, Implikacje ontologiczne typu redukcyjnego jako metoda uprawiania filozofii przez Księdza Profesora Kazimierza Kłósaka, w: Filozofia a nauka w myśli - Księdza Kazimierza Kłósaka, red. Z. Liana, A. Michalik, Kraków-Tarnów 2004, s. 63-88; Z. Hajduk, Filozofia przyrody - Filozofia przyrodoznawstwa. Metakosmologia, Lublin 2004, passim. Szerzej piszę o problemach interpretacji faktów naukowych w pracy: P. Duchliński, $W$ stronę aporetycznej filozofii klasycznej, Kraków 2014.

46 Zob. J. Woleński, W stronę logiki, dz. cyt., passim; J. Woleński, Logika, kontekst odkrycia, kontekst uzasadniania, w: Odkrycie naukowe i inne zagadnienia współczesnej filozofii i nauki. Pamięci Elżbiety Pietruskiej-Madej i Jana Żytkowa, red. W. Krajewski, W. Strawiński, Warszawa 2003, s. $75-$ 87; J. Woleński, O tak zwanych filozoficznych założeniach nauki, w: Z zagadnień filozofii nauk przyrodniczych, red. S. Butryma, Warszawa 1991, s. 7-16.

47 Warto skorzystać w punkcie wyjścia badania filozoficznego z propozycji sformułowanej przez Hellera. Jest to strategia niefundacjonalistyczna. „Jestem skłonny - pisze Heller - uznać krytyczną dyskusję za istotny element metody, którą nazwałem «metodą zapętleń», w każdym razie o ile ta jest stosowana w filozofii [...] Nie jest to łatwy postulat, ponieważ każda dyskusja (zwłaszcza z rzeczywistym przeciwnikiem) uruchamia pewne psychologiczne mechanizmy obrony i agresji. By się im przeciwstawić od samego początku, warto formułować swoje poglądy (nawet najbardziej uzasadnione) nie w formie kategorycznych stwierdzeń, lecz w postaci hipotez, pozostawiających odpowiednio szeroki margines na modyfikację lub przeformułowanie. Jednakże praca filozofa nie kończy się na wypowiedzeniu hipotezy. Hipoteza zostaje włączona w «nieliniowy cykl myślowy». W filozofii nie dochodzi się do wniosków, które można by potem odłożyć ad acta" (M. Heller, Przeciw fundacjonizmowi, w: M. Heller, Filozofia i Wszechświat, Kraków 2006, s. 100).

48 Zob. A. Bronk, Demarkacjonizm lubelskiej szkoły filozoficznej, „Roczniki Filozoficzne” 35 (1987) z. 1, s. 345-364. 
mu przecież o odpowiedź na pytanie „jak możliwe jest poznanie?”" odpowiedzieć na to pytanie, trzeba prześledzić, w jaki sposób poznanie to stopniowo się rozwija, w jaki sposób umysł ludzki nabywa określone kategorie i struktury, które pozwalają mu w taki, a nie inny sposób doświadczać świata realnego. Piaget był krytyczny względem wszelkiej spekulatywnej metafizyki poznania, nie uważał bowiem, że można uprawiać epistemologię, która nie potrafiłaby wylegitymować swoich rezultatów badawczych w uteoretyzowanym doświadczeniu empirycznym. Przeprowadzone przez niego badania mają na uwadze realizację określonych celów epistemologicznych. W całej tej dyskusji istotne jest to, że wyprowadzone na podstawie ontogenezy filozoficzne implikacje mają swoje testowe potwierdzenie w empirycznych faktach dotyczących rozwoju struktur poznawczych ${ }^{50}$. Wydaje się, że tym sposobem można pokazać, w jaki sposób tezy filozofii (metafizyki tomistycznej) mogą być potwierdzane lub też negatywnie testowane przez dane ontogenetyczne. Przykład pytań jest tutaj bardzo wymowny, dlatego że tak filozofowie, jak i psychologowie uważają, że odgrywają one w poznaniu świata i człowieka dosyć istotną rolę ${ }^{51}$. U podstaw pozytywnego podejścia do implikacji filozoficznych z ontogenezy tkwi założenie, że filozofia może dużo skorzystać z rezultatów badawczych nauk empirycznych. Mogą one być cennym dopełnianiem analiz semantycznych i ontologicznych, ponadto prowadzić do korekty szeregu egzotycznych twierdzeń, uważanych przez niektórych filozofów za ostatecznie prawdziwe i niekorygowalne. Zakłada to oczywiście taką koncepcję filozofii, która przynajmniej częściowo jest otwarta na rezultaty różnych nauk szczegółowych ${ }^{52}$. Jednak

49 J. Piaget, Psychologia i epistemologia, dz. cyt., s. 15.

50 Zob. J. Życiński, Zagadnienie możliwości falsyfikacji twierdzeń w filozofii przyrody, „Analecta Cracoviensia” 14 (1982), s. 94-98. Autor podaje przykłady z zakresu filozofii przyrody.

${ }^{51}$ Zob. R. Radwiłowicz, O pytaniach uczniowskich ogólnie, w: Pytania uczniów a treść nauczania, red. R. Radwiłowicz, K. Pauzewicz, C. Kosiński, Warszawa 1969, passim; R. Fisher, Stawianie pytań, w: R. Fisher, Uczymy jak uczyć, Warszawa 1999, passim.

52 „Istota sprawy polega na tym, że tezy ze współczynnikiem hermeneutycznym mogą być objaśnione w taki sposób, że stają się zrozumiałe dla osób operujących odmiennymi systemami hermeneutycznymi, krótko hermeneutykami, przez co nabywają intersubiektywnie komunikowalnego sensu, chociaż wcale nie muszą stać się empirycznie sprawdzalne. Zapewne wolno powiedzieć, 
bez przesadnej obawy o to, że utraci swój własny status epistemologiczny i metodologiczny.

(2) Wyniki badań ontogenezy potwierdzają na pewno to, że dzieci stawiają pytanie „dlaczego?” w sposób spontaniczny pod wpływem doświadczenia rzeczy lub czynności innych osób. Ponadto uprawomocniają, jakże często głoszoną przez filozofów tezę, że człowiek już od dziecka poszukuje informacji koniecznych nie tylko do zrozumienia świata, lecz także do skutecznego dostosowania się do niego. Na podstawie ontogenezy pytań uzyskujemy dynamiczny obraz ludzkiej wiedzy i poznania. Poznanie to proces, który z biegiem lat stale się komplikuje, o czym świadczy przyrost nowych czynności i operacji kognitywnych. Wielu współczesnych autorów bardzo mocno akcentuję tę dynamikę poznania, choć wielu jeszcze postępuje utartym torem ujęć tradycyjnych, traktują poznanie w sposób jakby „zamrożony”.

(3) Ontogeneza pytań implikuje także sceptyczne wnioski dotyczące ideału poznania bezinteresownego. Chodzi o taki typ poznania, w którym spełniamy określone czynności poznawcze tylko dla nich samych, nie zaś dla jakichś postronnych celów pragmatycznych czy utylitarnych. Można zastanawiać się, kiedy i w jakim momencie życia człowiek stawia pytania, które wyrażałyby jego poznawczą bezinteresowność? W perspektywie ontogenezy dziecko pyta o nazwy przedmiotów lub też o ich położenie tylko po to, aby móc nimi sprawniej się posługiwać. Poznanie jest tutaj na usługach innych celów, jak np. lepsze przystosowanie się do otoczenia czy poprawne wykonanie instrukcji sformułowanej przez dorosłego. Pierwotne cele dziecka, jak pokazuje Piaget, są typowo utylitarne. I jest to sytuacja całkowicie prawidłowa i normalna $\mathrm{z}$ punktu widzenia rozwojowego. Małe dziecko nie zapytuje tylko dla samego zapytywania, chyba że znajduje się jeszcze na bardzo wczesnym etapie ontogenezy, kiedy jedynie powtarza za dorosłymi określone dźwięki, których znaczenia bliżej nie rozumie lub też kiedy znajduje się w stanie 
chorobowym przejawiającym się np. w kompulsywnych zachowanych, które mogą objawiać się notorycznym stawianiem pytań formułowanych bez wyraźnego celu komunikacyjnego. Pojawia się problem, jak rozmieć poznanie bezinteresowne? Bezinteresowne dla kogo? Jeśli ma ono jakiś przedmiot, to musi być zawsze związane z jakimś zainteresowaniem tym przedmiotem. Gdyby zabrakło tego momentu zainteresowania, w ogóle nie spełnialibyśmy żadnych czynności kognitywnych. Po co mielibyśmy coś poznawać, gdyby to nas w ogóle nie interesowało? Tymczasem człowiek, jako podmiot poznania, zadaje mnóstwo różnych pytań zawsze w konkretnych celach. Nawet jeśli są to cele tylko teoretyczne, pozbawione odniesienia praktycznego, to nigdy nie czyni tego z czystej potrzeby poznawczej, bo takie potrzeby wyizolowane nie istnieją, lecz z określonych intencji i motywów praktycznych, które tkwią głęboko w jego umyśle. Stawiając pytanie „dlaczego”, szukamy określonych informacji, które nie tylko zaspokoją naszą potrzebę wiedzy, lecz także przyczynią się do uzyskania np. większego komfortu psychiczno-emocjonalnego, którego początkowy brak generuje tego typu pytania. Ideał poznania bezinteresownego ma charakter abstrakcyjnego postulatu, który daleki jest od tego, jak ludzie naprawdę poznają realną rzeczywistość. Ontogeneza czyni filozofii niemałą przysługę, pokazując, że u podstaw zadawania pytań nigdy nie kryje się żadna bezinteresowność, lecz zainteresowanie konkretnymi obiektami pytania (zainteresowanie realnym światem). Gdyby nie było tego zainteresowania, które nie musi mieć charakteru czysto utylitarnego, pytanie nigdy nie zostałoby postawione.

(4) Dane ontogenezy mogą podawać w wątpliwość niektóre tezy filozoficzne. Przykładowo według metafizyków tomistycznych dziecko stawia pytanie „dlaczego", gdyż pragnie zrozumieć ontyczną strukturę rzeczy. Tymczasem na podstawie ontogenezy dowiadujemy się, że dzieci stawiają to pytanie nie pod wpływem pobudek intelektualnych, ale pod wpływem pobudzenia emocjonalnego, wyrażającego się w zdziwieniu i zakłopotaniu. Trudno też zgodzić się z tezami, że wszystkie pytania dadzą się sprowadzić do pytania „dlaczego" lub że znajdują w nim ugruntowanie. Badania pytań dziecięcych dostarczają tezy przeciwnej. Pytanie „dlaczego" nie stanowi podstawy dla innych pytań. Nie można też innych 
pytań do niego zredukować. Wręcz przeciwnie, pytanie to musi zostać uzupełnione lub zastąpione innymi pytaniami. Odpowiedzi na pytanie „dlaczego" dostarczają wiedzy ogólnej, która domaga się uszczegółowienia za pomocą formułowania kolejnych pytań. Nie bardzo też wiadomo, na czym miałaby polegać redukcja wszystkich pytań do pytania „dlaczego”, którą proponują np. autorzy tomistyczni. Nie wiemy, czy chodzi tu o redukcję semiotyczną, czy może epistemologiczną, czy też o jakąś jeszcze inną. Przeważnie sensu tej redukcji się nie objaśnia (Krąpiec). Na podstawie ontogenezy możemy stwierdzić, że pytanie „dlaczego” nie jest dla rozwoju poznawczego w żaden sposób przesądzające, tzn. jego hipertrofia obejmuje tylko określony przedział rozwoju, który stopniowo się zmniejsza, ustępując miejsca innym typom pytań, nie mniej ważnym z ontogenetycznego punktu widzenia niż pytanie „dlaczego”. Wydaje się jednak, że tzw. pytania kategorialne bardziej przyczyniają się do rozwoju poznania, umożliwią bowiem zdybywanie wiedzy szczegółowej, która jest znacznie bardziej przydatna ze względów adaptacyjnych.

(5) Z ontogenezy pytań wynikają też dosyć istotne implikacje dla rozumienia realizmu ludzkiego poznania. Okazuje się, że nie jesteśmy realistami aż tak bardzo wiernymi rzeczywistości, jak tego od nas oczekują niektórzy filozofowie, zwłaszcza realistycznie nastawieni tomistyczni metafizycy. Badania nad wczesnym rozwojem kognitywnym dzieci dowodzą, że realizm dziecka nie jest realizmem wzrokowym, lecz intelektualnym. Prawidłowości związane z dziecięcym pojmowaniem realności odkrywamy na podstawie analizy formułowanych pytań modalnych. Dla dziecka rzeczywistość jest raczej czymś skonstruowanym niż biernie odzwierciedlonym ${ }^{53}$. Choć myślenie dziecka jest realistyczne, to jednak przebiega w duchu realizmu intelektualnego. Supozycje dziecka dotyczące realności są mniej stabilne niż supozycje osób dorosłych. Dla nas rzeczywistość jest bardziej stabilna, określona, poza tym człowiek dorosły odróżnia wyraźnie myśl od rzeczywistości. Potrafi przeprowadzać skomplikowane uzasadnienia logiczne, które dotyczą związków między sądami, a nie rzeczami. Z jednej strony dla dziecka rzeczywistość

53 Zob. J. Piaget, Mowa i myślenie dziecka, dz. cyt., s. 165. 
realna jest bardziej dowolna, dlatego że zasiedla ją świat myśli, uznawany za równie realny, jak przedmioty fizyczne. $Z$ drugiej strony świat dziecka jest bardzo ustabilizowany, $\mathrm{z}$ tego względu, że nie ma w nim żadnej przypadkowości ${ }^{54}$. Jeśli jednak chodzi o możliwość, to dla człowieka dorosłego jest ona pewnym stopniem realności. Natomiast dla dziecka możliwość nie jest żadnym stopniem realności, jest ona równie realna jak wszystko inne. To pokazuje, że nigdy nie jesteśmy realistami w takim znaczeniu, że odzwierciedlamy rzeczywistość, która uderza w nasz aparat „ostrzem swojego bytu”. Nigdy tej rzeczywistości konsekwentnie się nie trzymamy, ani jako dzieci, gdyż przyjmujemy postawę realizmu intelektualnego, ani też jako ludzie dorośli, dla których myśl i rzeczywistość nie łączą się ze sobą w sposób jednoznaczny. Z punktu widzenia ontogenezy poznania to, że człowiek potrafi oderwać się od rzeczywistości i operować tylko samymi myślami, jest przejawem normalnego realistycznie pojętego rozwoju. Kurczowe trzymanie się rzeczy jest natomiast przejawem myślenia egocentrycznego, dla którego świat i myśl to niezróżnicowana całość. Poza tym wszelkie operacje formalne pojawiające się na dobre między 11 a 12 rokiem życia mogą być przeprowadzone z powodzeniem tylko dlatego, że jesteśmy w stanie oderwać myśl od realnej rzeczy i skoncentrować się na samych operacjach intelektualnych mających powtarzalny charakter, np. operacje matematyczne. Dlatego też alternatywa poznawać albo myśleć, lansowana przez tomistów, z punktu widzenia danych ontogenezy nie ma żadnego potwierdzenia $^{55}$. Poznawanie i myślenie są do tego stopnia ze sobą powiązane, że trudno byłoby w rozwoju człowieka wskazać taki moment, w którym by myślał, a nie poznawał, i na odwrót. To, że potrafimy myśleć, odrywając się od rzeczy, nie jest przejawem degeneracji, lecz normalnego rozwoju. Przykłady kliniczne osób z zaburzeniami autyzmu, egocentryzmu dobrze pokazują, co dzieje się z człowiekiem, kiedy stale pozostaje na poziomie realizmu intelektualnego. Filozofowie jednak

54 Zob. J. Piaget, Mowa i myślenie dziecka, dz. cyt., s. 186-187.

55 Zob. M. A. Krąpiec, Poznawać czy myśleć. Problemy epistemologii tomistycznej, Lublin 2000, passim. 
mają tendencję do wygłaszania abstrakcyjnych twierdzeń, sprzecznych z poprzednio wyartykułowanymi, gdyż nie biorą pod uwagę danych empirycznych dotyczących rozwoju poznawczego dzieci. Piaget trafnie podsumowuje te sytuację: „Dziecko daje bezustannie dowody realizmu intelektualnego, to znaczy, że jest ono zbyt realistą, ażeby być logikiem, a zbyt intelektualistą, ażeby być czystym obserwatorem. Świat fizyczny i świat myśli stanowią jeszcze dla niego tylko niezróżnicowany splot, przyczynowość i motywacja są jeszcze ze sobą pomieszane. Niewątpliwie u dorosłego, z wyjątkiem metafizyka albo naiwnego realisty, związek faktów i pojęć stanowi również jedność w tym sensie, że logika i rzeczywistość stanowią dwa szeregi nierozdzielnie ze sobą związane. Człowiek dorosły jednak dostatecznie się już wyodrębnił od swojego Ja i od swoich idei, ażeby być obiektywnym obserwatorem, i dostatecznie się oderwał od rzeczy, ażeby umieć rozumować na podstawie supozycji albo hipotez, traktowanych jako takie. Dlatego też myśl jego będąc podwójnie wyzwolona, jest zarazem podwójnie przystosowana. U dziecka natomiast myśli przeszkadzają obserwacjom, zaś obserwacje myślom, a stąd wynika jednakowa i współzależna nieznajomość rzeczywistości i logiki”56.

Filozofowie mają prawo do nadawania pytaniu „dlaczego” takich interpretacji, które wypływają z przyjmowanych przez nich przedzałożeń. A że każdy z filozofów przyjmuje treściowo odmienne przedzałożenia, stąd też tyle różnic w interpretacji pytania „dlaczego” zachodzących między tomistami a zwolennikami Leibniza czy Heideggera. Ontogeneza pokazuje tylko, w jaki sposób logika tych pytań się rozwija. Nie przesądza jednak o żadnej ich wykładni metafizycznej. Tomiści powołują się często na psychologię, która, w ich przekonaniu, ma potwierdzać spontaniczny realizm jako naturalną postawę poznawczą, a tym samym ugruntowywać przekonanie, że byt jest pierwszym przedmiotem poznania ${ }^{57}$. I faktycznie psychologia potwierdza, że realizm jest naturalną postawą poznawczą dziecka, tylko że nie jest to taki realizm jak ten, o którym

56 J. Piaget, Mowa i myślenie dziecka, dz. cyt., s. 188.

57 Jest to tylko jedna z hipotez interpretacyjnych. Choć tomiści uważają, że jest to wykładnia ostateczna. 
piszą tomistyczni metafizycy. Nie jest to realizm bezpośredni, związany $\mathrm{z}$ odzwierciedlaniem $\mathrm{w}$ procesach poznawczych rzeczy realnie istniejących, lecz realizm intelektualny (konstrukcyjny).

(6) Na podstawie danych ontogenezy dowiadujemy się, że dziecko formułuje swoje pytania w pierwszej kolejności nie pod adresem rzeczy, ale pod adresem wykonywanych czynności. „Pierwsze pytania «dlaczego?» dotyczą na ogół czynności ludzkich. Pierwsze pytanie zanotowane przez Scupina u Bubi jest tego rodzaju. Matka dziecka leżała na podłodze. Chłopczyk chciał ją podnieść... «du bist ja nicht tot, warum stehste nicht immersu auf?». Drugie takie pytanie pojawiło się, gdy dziecku zabroniono obrywać płatki kwiatów: «Warum denn?». Ale nawet u tych dzieci, które zaczynają od «dlaczego odnoszącego się do wyjaśnienia», trudno nie dopatrzyć się w żądnym wyjaśnieniu nie tylko wyjaśnienia przedprzyczynowego, lecz nawet takiego wyjaśnienia, w którym przedprzyczynowość zlewa się prawie zupełnie z przyczynowością psychologiczną albo intencjonalną: "Dlaczego drzewa mają liście»" ${ }^{8}$. Realny byt nie jest zatem w centrum uwagi dziecka. Kiedy zaś staje się przedmiotem jego uwagi, dziecko zadaje pod jego adresem pytania „dlaczego" dotyczące przyczynowości animistycznej lub artificjalnej. Nie dąży pierwotnie do zrozumienia natury rzeczy pod kątem posiadanych przez nią relacji czy też czynników ją konstytuujących. Nie bierze również pod uwagę żadnych przyczyn sprawczych o charakterze zewnętrznym czy wewnętrznym. Ich poszukiwane przychodzi z czasem, kiedy dziecko opanowuje posługiwanie się kategorią przyczynowości mechanicznej. To pokazuje, że nasze pierwotne zainteresowanie światem nie dotyczy wcale zrozumienia rzeczy, lecz intencji, motywów oraz sił. W początkowym okresie ontogenezy nie jesteśmy zainteresowani zrozumieniem struktury przedmiotu, ale intencjami, jakie się za nim kryją. Dlatego $\mathrm{w}$ centrum jest przyczynowość finalistyczna. Wszystko to związane jest rozwojem intencjonalnym osoby, która doświadcza tego, co realne w postaci oporu na tle coraz bardziej wyraźnie rysującego się niedopasowania jej pragnień i myśli do rzeczywistości. To na kanwie tego

58 J. Piaget, Mowa i myślenie dziecka, dz. cyt., s. 203. 
niedopasowania kształtuje się pierwotna intencjonalność umysłu dziecka i zaczyna się proces zasiedlania świata nową ontologią, która zakłada istnienie ukrytych intencji i sił, decydujących o zachodzeniu różnych zjawisk i przedmiotów.

Dane ontogenezy mogą być trudne do przedmiotowego uzgodnienia ze sformułowaniami, w których pisze się np.: „Pytanie [«dlaczego» P. D.] to jest pytaniem spontanicznym, które i dzieci i dorośli stawiają wówczas, gdy coś nie jest oczywiście zrozumiałe - gdy są jakieś czynniki ukryte, niezrozumiałe dla stanu rzeczy. Pytanie «dlaczego» jest związane zasadniczo ze stroną zrozumienia rzeczy poznawalnej" ${ }^{99}$. Dziecko wprawdzie szuka czynników, ale dotyczących w pierwszej kolejności zrozumienia ludzkich czynności, a nawet kiedy szuka ich w rzeczy, to chodzi mu o intencje i ukryte siły, a nie o analogiczne relacje, które konstytuują strukturę bytu. Przytoczone za autorem sformułowanie pokazuje, w jaki sposób dokonują się w filozofii wysoce uteoretyzowane interpretacje doświadczenia świata realnego, w którym pytania odgrywają określoną rolę.

(7) Wielu filozofów wprost deklaruje, że celem przedsięwzięcia filozoficznego powinno być znalezienie ostatecznych przyczyn wyjaśniających rzeczywistość (tomiści). To poszukiwanie ostatecznych wyjaśnień ma bardzo długą historię i wiąże się z pewną tendencją do budowania maksymalistycznych systemów filozoficznych, w ramach których wszystko mogłoby uzyskać ostateczne zrozumienie w oparciu o jakiejś bezpośrednie dane, niepodlegające żadnej epistemologicznej problematyzacji. Ta cecha filozoficznego badania jest dziś kwestionowana z pozycji wielu nurtów filozoficznych. Odrzucają ją filozofowie kontynentalni wywodzący się z hermeneutyki i postmodernizmu, jak również filozofowie nauki i analitycy różnego autoramentu. Jak wygląda ten problem z punktu widzenia ontogenezy? Otóż z punktu widzenia ontogenezy poznania skłonność do ostatecznego wyjaśniania wszystkiego jest cechą myślenia dziecka między 3 a 7 rokiem życia. W tym okresie dziecko nie posługuje się pojęciem przyczynowości mechanicznej ani uzasadnieniem

59 M. A. Krąpiec, Filozofia co wyjaśnia, dz. cyt., s. 37. 
logicznym. W jego myśleniu dominuje zdecydowanie antropomorfizm i artyficjalizm. Dziecko żywi przekonanie, że wszystko jest ze wszystkim powiązane na zasadzie pewnej konieczności. W świecie dziecka nie ma bowiem przypadku. Dlatego poszukuje ono wyjaśnień, które bardzo często z punktu widzenia wieku późniejszego nie mają żadnego sensu. Dobrze pokazują to testy dotyczące zaniku pojęcia przedprzyczynowości u dzieci między 7 a 8 rokiem życia. W świecie dziecka, jak wspomniano, nie ma jeszcze pojęcia przypadku, ono pojawia się znacznie później, w momencie kiedy dziecko odkrywa prawidłowości dotyczące życia i śmierci. W świecie ludzi dorosłych jest inaczej. Wszystko nie jest powiązane ze wszystkim. Istnieją przypadkowe wydarzenia i okoliczności, w których przecinające się łańcuchy przyczynowe nie są poznawalne. Dla człowieka dorosłego istnieją wydarzenia i sytuacje, których nie można wyjaśnić, a tym bardziej nie można ich wyjaśnić na siłę, w sposób ostateczny, odwołując się do czynników sprzecznych z posiadaną wiedzą, czy też antropomorficznych, sugerujących istnienie w rzeczach ukrytych sił i intencji. Dorośli tolerują jednak pytania dziecka, nawet jeśli z punktu widzenia posiadanej wiedzy nie mają one żadnego sensu poznawczego. Etap notorycznego poszukiwania powiązania wszystkiego ze wszystkim i wyjaśnień opartych na pomieszanych w umyśle dziecka typach konieczności właściwy jest dla etapu myślenia egocentrycznego. Dziecko widzi świat przy pomocą percepcji i myślenia synkretycznego jako całość powiązanych zjawisk, bez specjalnego zwracania uwagi na niuanse i szczegóły. To sprawia, że np. w miejsce przestrzennej styczności przedmiotów wprowadza ukryte siły i intencje. Czy z tego wynikałoby, że filozofowie, którzy czasem $\mathrm{z}$ uporem maniaka poszukują ostatecznych wyjaśnień, nie wyrośli jeszcze z egocentrycznego etapu myślenia? Czy nadal znajdują się oni w świecie, w którym nie ma przypadku, gdzie wszystko jest ze sobą powiązane na zasadzie wewnętrznej konieczności? Gdyby literalnie odnieść ustalenia ontogenezy do „roboty” filozoficznej, można by stwierdzić, że faktycznie niektórzy filozofowie to nic innego jak „duże dzieci", które przekrzykują się między sobą, kto ma lepsze ostateczne uzasadnienie świata. Być może dla wielu takie konstatacje są wyrazem pewnego nieporozumienia świadczącego o tym, że piszący tak naprawdę 
nie rozumie, na czym polega przedsięwzięcie filozoficzne. W tej sarkastycznej uwadze chodzi jednak bardziej o zwrócenie uwagi na pewien typ psychologicznej mentalności, która znamionuje myślenie filozoficzne, niż o wytykanie innym filozofom, że myślą jak małe dzieci. Przecież dojrzały filozof, który rzetelnie opanował warsztat badawczy, dobrze wie (być może raczej powinien wiedzieć), że takich ostatecznych uzasadnień w sferze tak abstrakcyjnych teorii, jak filozofia nie można osiągnąć bez przyjęcia szeregu konwencjonalnych decyzji ${ }^{60}$. Rzeczywistość sama nie nasuwa bowiem żadnych określonych rozstrzygnięć ontologicznych i semantycznych. Nie sugeruje żadnej gry językowej, która mogłaby spełniać rolę uniwersalnego słownika dostarczającego opisu wszystkich faktów i zachodzących między nimi zależności. Niezależnie jednak od tego, czy filozofowie przejawiają skłonność do myślenia egocentrycznego, trzeba stwierdzić, że ontogeneza dostarcza wystarczających dowodów, empirycznie potwierdzonych, iż ostateczne uzasadnienia w przypadku prawidłowo i normalnie rozwiniętego aparatu poznawczego są trudne do zaakceptowania ${ }^{61}$. Na poziomie uzasadnień logicznych nigdy nie

60 Kwestie te mogą być szerzej przebadane w ramach tzw. psychologii filozofowania, która wskazuje na pewne korelacje zachodzące miedzy osobowością filozofa a tworzoną przez niego teorią. Szerzej zob. J. Pieter, Psychologia filozofowania, Katowice 2005. Trzeba bowiem pamiętać o tym, że na akceptację określonego paradygmatu filozofowania mają wpływ czynniki podmiotowe. W Polsce pisał o tym Józef Życiński.

${ }^{61}$ Oczywiście, zbyt wrażliwy na punkcie swoich poszukiwań filozof może odebrać te stwierdzenia jako deprecjonujące jego twórczą pracę. Autorowi tych uwag chodzi jednak nie tyle o deprecjonowanie filozofów, ale o próbę realistycznego podejścia do tego, na czym polega tzw. filozoficzna dobra robota. W przekonaniu piszącego jest ona niczym innym, jak tylko próbą zmierzenia się z określonymi tzw. sytuacjami problemowymi, które pojawiają się tak w obszarze samej filozofii, jak i na styku różnych nauk, np. filozofii i nauk empirycznych lub filozofii i nauk społecznych. Konfrontacja z sytuacją problemową wyzwala wstępne hipotezy interpretacyjne, których celem jest objaśnienie tej sytuacji problemowej, bez wskazywania na jakieś magiczne ostateczne rozstrzygniecie. Hipotezy te mają mocne osadzenie w dotychczasowej wiedzy, która doprowadziła do powstania sytuacji problemowej. W tym znaczeniu, jeśli ktoś w punkcie wyjścia dekretuje, że już ostatecznie rozstrzygnął sytuację problemową, za pomocą wypowiedzianej z pewną dozą patetyzmu formuły, to wydaje się, że przejawia on pewną „dziecięcą" manierę, że wszystko musi być koniecznie tak jak on myśli i postanawia w obrębie swojej koncepcji. Świat jest taki, jak głosi jego koncepcja, inaczej być nie może, a wszystkie inne koncepcje są błędne, tylko z tego powodu, że przyjmują odmienne założenia niż jego własna koncepcja. Te niefortunne w moim przekonaniu tezy są właśnie 
mamy do czynienia z ostateczną pewnością, chyba że sami tak zadekretujemy. A taka postawa może być dla niektórych przejawem megalomanii i napuszonego dogmatyzmu, opornego na wszelką refutację. Obiektywizacja myślenia dokonuje się zawsze w konfrontacji z innymi, którzy zazwyczaj mają odmienne punkty widzenia na te same przedmioty, wydarzenia i innych ludzi. To już prowadzi do konstatacji, że nie ma jednego punktu widzenia, nie tylko w świecie doświadczenia codziennego, lecz także w nauce, która jest do tego stopnia demokratyczna, że dopuszcza wielość różnych perspektyw, od których jednak domaga się empirycznego potwierdzenia. Filozofia cieszy się w tej materii znacznie większą dowolnością niż nauka, nie musi bowiem w doświadczaniu testować swoich twierdzeń.

(8) Dane ontogenezy obalają też mit głoszony przez pozytywistów, że nasze poznanie w całości wywodzi się z danych zmysłowych. Nie spostrzegamy żadnych wrażeń ani danych zmysłowych. Kiedy spostrzegamy drzewo, to nie widzimy najpierw pnia, kory, liści i gałęzi, ale od razu spostrzegamy pewną całość, pewien określony Gestalt. Poznanie przedmiotu nie ma charakteru biernego. Związane jest $\mathrm{z}$ oddziaływaniem na niego oraz z przekształcaniem go poprzez asymilację. To, co spostrzegamy, jest współkształtowane przez operacje logiczno-matematyczne. „Doświadczenie jest możliwe jedynie za pośrednictwem form logiczno-matematycznych, składających się z klasyfikacji, przypisywania porządku, odpowiedniości, funkcji itp. Odczytywanie danych spostrzeżeniowych samo przez się zakłada udział takich form lub ich bardziej lub mniej zróżnicowanych zarysów"62. Wiele pojęć, którymi posługujemy się zarówno na co dzień, jak i w nauce, nie pochodzi wprost $\mathrm{z}$ doświadczenia ${ }^{63}$. Takie pojęcia, jak czas, przestrzeń, przyczynowość nigdy

konsekwencją określonych podmiotowych uwarunkowań, w których dominuje element wizjonerski, a nie logiczne uzasadnienie tez. I tutaj jest właśnie pole dla badań takiej metanauki, jak psychologia filozofowania.

${ }^{62}$ J. Piaget, Psychologia i epistemologia, dz. cyt., s. 82.

63 Świat realny nie jest otwartą księgą, z której można dowolnie wyczytać jakąkolwiek teorię. Aby cokolwiek z tego świata „wyczytać”, trzeba przyjąć szereg różnych założeń teoretycznych, choćby najbardziej podstawowych, jak te, które dotyczą semantyki języka. Metafora „czytania świata” 
nie mogłyby zostać wyprowadzone z doświadczenia, gdyby nie udział coraz bardziej skomplikowanych operacji formalnych. Aby uzyskać np. pojęcie przestrzeni czy przyczynowości, konieczne jest powiązanie danych, których dostarcza doświadczenie, z czynnościami i operacjami formalnymi podmiotu stanowiącymi układ określonych stosunków logicznych i matematycznych, bez których podmiot nigdy nie mógłby asymilować żadnych przedmiotów ${ }^{64}$. Spostrzeganie zawsze zakłada udział czynników konceptualnych, mniej lub bardziej rozwiniętych wnioskowań, za pomocą których dokonuje się przekształcanie danych dostarczanych przez spostrzeżenie w coraz bardziej złożone struktury operacyjne. Wszystko to wspiera argumentację przeciwko wszelkiego rodzaju propozycjom bezzałożeniowych i neutralnych punktów wyjścia (tomizm), których zwolennicy poszukują niekwestionowanych i ateoretycznych danych. Tym bardziej trudno jest ich bronić w przypadku tak teoretycznie zaawansowanych teorii, z jakimi mamy do czynienia w filozofii/metafizyce. Można powiedzieć, że dziecięce pytania „dlaczego" są uteoretyzowane tylko w stopniu nieznacznym, co związane jest $\mathrm{z}$ brakami konceptualnymi i ubóstwem słownictwa językowego. Natomiast w przypadku filozofii każde postawione pytanie zakłada szereg bardzo mocnych założeń teoretycznych, bez których sformułowanie go byłoby pragmatycznie niemożliwe. Całkowita neutralność i bezzałożeniowość mogłaby występować jedynie w przypadku tzw. surowego czucia i obejmowałaby bardzo wczesny okres życia małego dziecka, które nie nabyło jeszcze umiejętności posługiwania się językiem i kategoryzowania danych percepcyjnych. Dlatego na żadnym etapie ontogenezy poznanie nie polega na biernym odczytywaniu danych spostrzeżeniowych. W każdym wszak doświadczeniu są zaangażowane określone czynności i operacje formalne. Same już bowiem spostrzeżenia organizują się $\mathrm{w}$ taki sposób, że powstaje w nich zarys pojęcia ${ }^{65}$. Piaget zwraca uwagę,

nasuwa błędne skojarzenia, jakoby dało się tworzyć teorie bez przyjmowania jakichkolwiek założeń. Samo jednak otwarcie oczu nie wystarcza do tego, aby poznawać świat realny, o czym dobrze informuje nas np. teoria ontogenezy Piageta.

64 Zob. J. Piaget, Psychologia i epistemologia, dz. cyt., s. 95-96.

65 Zob. J. Piaget, Psychologia i epistemologia, dz. cyt., s. 90. 
że w organizacji pojęć biorą udział schematy zmysłowo-ruchowe, które z punktu widzenia ontogenezy odgrywają dosyć istotną rolę, prowadzą bowiem do przekształcenia danych percepcyjnych $\mathrm{w}$ wyższe jednostki operacyjne. Im bardziej rozwój poznawczy postępuje i komplikuje się, tym bardziej ludzkie poznanie odrywa się od rzeczy i koncentruje na uzasadnieniu logicznym sądów ${ }^{66}$. Nie oznacza to jednak, że człowiek traci zainteresowanie światem realnym. Nadal przecież w nim żyje i wszystkie czynności kognitywne podporządkowuje pozyskiwaniu informacji, które pozwalają na skuteczne dostosowanie się do niego, ale już nie na zasadzie egocentrycznej czy animistycznej, ale właśnie realistycznej ${ }^{67}$. Zdolność do myślenia oderwanego od rzeczy jest oznaką normalnego rozwoju psychiczno-poznawczego. Przyczynia się do wypracowania zdolności coraz sprawniejszego posługiwania się operacjami formalnymi, w których nie chodzi o rzeczy, lecz o związki między sądami i pojęciami. Wszystko to nie jest przejawem żadnego aprioryzmu, idealizmu ani też degeneracji poznania ${ }^{68}$, będącej konsekwencją odejścia od jakiejś wzorcowej doktryny filozoficznej, ale normalnego i prawidłowego rozwoju, który określiła swoimi prawami ewolucja bio$\operatorname{logiczna}{ }^{69}$. W związku z tym dylemat „poznawać czy myśleć” z punktu widzenia ontogenezy jest bezzasadny i empirycznie nieuzasadniony. Myślenie i poznawanie to pewna jedność (całość) funkcjonalna, której nawet dla potrzeb głębszej analizy epistemologicznej nie ma sensu rozbijać ${ }^{70}$. W całości kognitywnego funkcjonowania człowieka trudno

66 Zdaniem tomistów egzystencjalnych zdolność abstrakcji jest właśnie odpowiedzialna za to, że odrywamy się od tego, co realne, a koncentrujemy tylko na ujęciach myślowych, istotowych.

67 Postawa realistyczna to właśnie taka, która abstrahuje od rzeczy, a nie kurczowo jej się trzyma.

68 Tezy bardzo często spotykane w różnych pracach autorów tomistycznych, np. u Gilsona i Krąpca oraz jego uczniów, którzy zasadniczo ograniczają się do powtarzania jego opinii.

69 Pomijam w tym miejscu szerszy kontekst dyskusji nad wykorzystaniem danych teorii ewolucji w epistemologii filozoficznej. Szerzej problemy te były omawiane w ramach ewolucyjnej teorii poznania, którą trzeba wyraźnie odróżnić od koncepcji ontogenezy w ujęciu Piageta.

70 Tomiści zgadzają się z tym, że ludzkie poznanie to pewna całość funkcjonalna. Podtrzymują jednak tę alternatywę, zwłaszcza w krytyce różnych systemów idealistycznych. Realizm wiążą z poznaniem, a idealizm z myśleniem oderwanym od konkretu. Myślenie abstrakcyjne jest podejrzane właśnie dlatego, że jest myśleniem oderwanym od realnego konkretu. Teza ta ma charakter 
byłoby znaleźć takie momenty, w których on albo wyłącznie myśli, albo wyłącznie poznaje. Chyba jedynie niektórzy filozofowie (tomiści) wiedzą, gdzie kończy się jedno, a gdzie zaczyna drugie, i kto funkcjonuje w ten właśnie sposób. Dlatego w tej kwestii potrafią być prawdziwymi mistrzami przeprowadzania dystynkcji, pytanie tylko czy fortunnych...

\section{Uwagi końcowe}

Z przeprowadzonych analiz wynika, że wnioski wyprowadzone $\mathrm{z}$ ontogenezy poznania mogą kwestionować szereg ustaleń w zakresie metafizyki poznania dotyczących statusu pytania „dlaczego", natury poznania i jego celów, stosunku języka do świata oraz realizmu poznania i sposobu jego uzasadnienia. Wnioski te nie przesądzają jednak ostatecznie o wartości jakiegokolwiek przedsięwzięcia metafizycznego. Dlatego nie trzeba traktować ich w sposób normatywny. Z pewnością przez wielu zostaną odrzucone, co w filozofii jest sytuacją całkowicie normalną, i nie powinno wywoływać zbyt wygórowanych emocji. Filozof jest w sytuacji pewnej dowolności - w swoich analizach może uwzględniać dane pochodzące $z$ nauk empirycznych, ale nie musi tego czynić. Równie dobrze może twierdzić, że nie są one w żaden sposób rozstrzygające dla filozofii ${ }^{71}$. Jednak kiedy przyjmujemy wieloaspektowe podejście do badania problemów filozoficznych, musimy uwzględnić rozstrzygnięcia nauk empirycznych ${ }^{72}$. W przypadku epistemologii może chodzić np. o dane psychologii rozwojowej. Nie tylko pozwalają one skorygować

konceptualny (spekulatywny), nie jest uzasadniona w żadnych danych doświadczenia, bowiem ono potwierdza akurat jej odwrotność: że myślenie i poznanie to całość, która ma charakter realistyczny. Realizm nie jest tylko realizmem poznania, ale też realizmem myślenia, zdolnego oderwać się od tego, co konkretne i jednostkowe.

${ }^{71}$ Tomiści egzystencjalni uważają, że tzw. fakty naukowe nie mogą podważać tez filozoficznych, gdyż znajdują się w zupełnie innej płaszczyźnie epistemologicznej niż poznanie filozoficzne. Stąd też autorzy tomistyczni odrzucą zaproponowaną argumentację, jako próbę narzucenia a priori filozofii danych pochodzących z ontogenezy, czyli z innej płaszczyzny poznawczej.

72 Zob. J. Życiński, Filozofować w kontekście nauki, w: Rozmowy o filozofii, red. A. Zieliński, M. Bagiński, J. Wojtysiak, Lublin 1996, s. 213-248; J. Życiński, Wpływ nauk szczegółowych na rozwój filozofii, w: J. Życiński, Teizm i filozofia analityczna, t. 2, Kraków 1988, passim. 
określone twierdzenia metafizyki poznania, lecz także zabezpieczają przed głoszeniem egzotycznych tez, które nie mają żadnego potwierdzenia w rozwoju psychiczno-poznawczym człowieka. Ontogeneza nie pokazuje, że trzeba zrezygnować z posługiwania się pytaniem „dlaczego” w dyskursie filozoficznym. Sugeruje tylko, że może nie jest to pytanie najważniejsze dla tożsamości metodologicznej filozofii, a zwłaszcza dla metafizyki. Może należy je ujmować w kontekście razem z wszystkimi innymi pytaniami stawianym przez podmiot poznający, gdyż tylko wtedy otrzymamy bardziej realistyczny obraz sytuacji poznawczej człowieka, który zadaje różne pytania, poszukując mniej lub bardziej trwałych odpowiedzi.

Warto zatem dogłębnie przemyśleć wynikające $\mathrm{z}$ ontogenezy poznania implikacje metateoretyczne dla konstruowania teorii filozoficznej. Być może okażą się one pomocne w coraz bardziej realistycznym ukazywaniu struktury i funkcji ludzkiego poznania w jego wieloaspektowych związkach z realną rzeczywistością.

\section{Bibliografia}

Ajdukiewicz K., Analiza semantyczna zdania pytajnego, „Ruch Filozoficzny” 10 (1926), s. 194-195.

Ajdukiewicz K., O intencji pytania „,Co to jest?”, , Ruch Filozoficzny” 7 (1923), s. 152-153.

Brożek A., O pojęciach rozstrzygalności i nierozstrzygalności w świetle teorii pytań, w: Філософсвкі проблеми науки/Filozoficzne problemy nauki, red. A. Brożek, ЛьвівWarszawa 2008, s. 355-363.

Brożek A., O pytaniach filozoficznych i ich rozstrzygalności, „Studia Philosophiae Christianae" 45 (2009) nr 1, s. 7-25.

Brożek A., Pytania i odpowiedzi. Tło filozoficzne, teoria, zastosowania praktyczne, Warszawa 2007.

Duchliński P., W stronę aporetycznej filozofii klasycznej, Kraków 2014.

Fisher R., Stawianie pytań, w: R. Fisher, Uczymy, jak uczyć, Warszawa 1999.

Hajduk Z., Filozofia przyrody - filozofia przyrodoznawstwa. Metakosmologia, Lublin 2004. Kamiński S., Jak filozofować. Studia z metodologii filozofii klasycznej, Lublin 1989. 
Kielar-Turska M., Przedmowa w: J. Piaget, Mowa i myślenie dziecka, tłum. J. Kołudzka, Warszawa 2005, s. 3-10.

Kielar-Turska M., Średnie dzieciństwo. Wiek przedszkolny, w: Psychologia rozwoju człowieka. Podręcznik akademicki, red. J. Trempała, Warszawa 2011, s. 83-129.

Koj L., Analiza pytań I. Problem terminów pierwotnych logiki pytań, „Studia Semiotyczne” 2 (1971), s. 99-113.

Koj L., Analiza pytań II. Rozważania nad struktura pytań, „Studia Semiotyczne” 3 (1973), s. 22-39.

Krąpiec A. M., DIÁ TÍ, http://www.ptta.pl/pef/pdf/d/diati.pdf (31.01.2018).

Krąpiec A. M., Filozofia co wyjaśnia, Lublin 1999.

Krąpiec A. M., Metafizyka. Zarys teorii bytu, Lublin 1994.

Krąpiec A. M., O rozumienie filozofii, Lublin 1995.

Krąpiec A. M., Poznawać czy myśleć: problemy epistemologii tomistycznej, Lublin 2000.

Krüger H. H., Wprowadzenie w teorie i metody badawcze nauk o wychowaniu, tłum. D. Sztobryn, oprac. B. Śliwerski, Gdańsk 2005.

Kubiński T., Analiza logiczna pojęć a założenia pytania, w: Rozprawy filozoficzne, red. L. Gumański, Toruń 1969, s. 189-200.

Kubiński T., O pojęciu pytania i rachunku operatorów pytajnych, „Ruch Filozoficzny” 25 (1966) nr 1-2, s. 70-74.

Pelc J., O poznawczej roli pytań, w: Prace z pragmatyki, semantyki i metodologii semiotyki, red. J. Pelc, Wrocław 1991, s. 191-200.

Piaget J., Jak dziecko wyobraża sobie świat, tłum. M. Gawlik, Warszawa 2006.

Piaget J., Mowa i myślenie dziecka, tłum. J. Kołudzka, Warszawa 2005.

Piaget J., Psychologia i epistemologia, tłum. Z. Zakrzewska, Warszawa 1977.

Pieter J., Psychologia filozofowania, Katowice 2005.

Psycholingwistyka, red. G. Gleason, J. \& B. N. Ratner, tłum. J. Bobryk, Gdańsk 2005.

Radwiłowicz R., O pytaniach uczniowskich ogólnie, w: Pytania uczniów a treść nauczania, red. R. Radwiłowicz, K. Pauzewicz, C. Kosiński Warszawa 1969, s. 7-21.

Stępień B. A., Wprowadzenie do metafizyki, Kraków 1964.

Stróżewski W., Istnienie i sens, Kraków 1994.

Stróżewski W., O zasadnicze pytanie metafizyki, „Znak” 127 (1965), s. 3-23.

Szuman S., Rozwój pytań dziecka. Badania nad rozwojem umysłowości dziecka na tle jego pytań, w: S. Szuman, Dzieła wybrane, t. 1: Studia nad rozwojem psychicznym dziecka, wybór i opracowanie M. Przetacznikowa, G. Makiełło-Jarża, Warszawa 1985, s. 274-321. 
Szuman S., Rozwój pytań dziecka. Badania nad rozwojem umysłowości dziecka na tle jego pytań, Warszawa 1939.

Turek J., Filozoficzne interpretacje faktów naukowych, Lublin 2009.

Turek J., Implikacje ontologiczne typu redukcyjnego jako metoda uprawiania filozofii przez Księdza Profesora Kazimierza Kłósaka, w: Filozofia a nauka w myśli - Księdza Kazimierza Kłósaka, red. Z. Liana, A. Michalik, Kraków-Tarnów 2004, s. 63-88.

Wiśniewski A., The Posing of Questions: Logical Foundations of Erotetic Inferences, Dordrecht-Boston-London 1995.

Wojtysiak J., „Dlaczego istnieje raczej coś niż nic?” Analiza problemu w kontekście dyskusji we współczesnej filozofii analitycznej, Lublin 2008.

Wojtysiak J., O zasadzie racji dostatecznej, „Roczniki Filozoficzne” 54 (2006) nr 1, s. 179-21.

Woleński J., Logika, kontekst odkrycia, kontekst uzasadniania, w: Odkrycie naukowe i inne zagadnienia współczesnej filozofii i nauki. Pamięci Elżbiety Pietruskiej-Madej i Jana Żytkowa, red. W. Krajewski, W. Strawiński, Warszawa 2003, s. 75-87.

Woleński J., O tak zwanych filozoficznych założeniach nauki, w: Z zagadnień filozofii nauk przyrodniczych, red. S. Butryma, Warszawa 1991, s. 7-16.

Woleński J., W stronę logiki, Kraków 1996.

Zamiara K., Epistemologia genetyczna Piageta a społeczny rozwój nauki, WarszawaPoznań 1979.

Zamiara K., Epistemologiczne założenia psychologicznej wizji człowieka, w: Materiały XXVI Zjazdu PTP, Szczecin 1987, red. E. Aranowska, Warszawa 1991.

Zamiara K., Kilka uwag o Piagetowskiej koncepcji świadomości i jej znaczeniu dla badań nad kultura, „Nowa Krytyka” 1991 nr 1, s. 33-44.

Zamiara J., Obecność myślenia psychologicznego w epistemologii, w: Rozprawy i szkice z filozofii i metodologii nauk, red. J. Such i in., Warszawa-Poznań 1992.

Życiński J., Filozofować w kontekście nauki, w: Rozmowy o filozofii, red. A. Zieliński, M. Bagiński, J. Wojtysiak Lublin 1996, s. 213-248.

Życiński J., Wpływ nauk szczegółowych na rozwój filozofii, w: J. Życiński, Teizm i filozofia analityczna, t. 2, Kraków 1988.

Życiński J., Zagadnienie możliwości falsyfikacji twierdzeń w filozofii przyrody, „Analecta Cracoviensia” 14 (1982), s. 94-98. 


\section{Abstrakt}

\section{Ontogeneza pytania „dlaczego” w perspektywie epistemologii genetycznej i jej filozoficzne implikacje}

Pytanie „dlaczego” uważa się za jedno z najważniejszych pytań filozoficznych. Wielu filozofów sądzi, że decyduje ono o profilu i tożsamości dyskursu filozoficznego. Wszelkie zaś próby jego odrzucenia postrzega się jako przejaw tendencji minimalistycznych w badaniach filozoficznych. W artykule przedstawiono poglądy J. Piageta na ontogenezę pytania „dlaczego”. Po ich zrekonstruowaniu ujawniono, jakie implikacje filozoficzne mogą $\mathrm{z}$ nich wynikać. Autor artykułu argumentował, że dane ontogenezy mogą odgrywać heurystyczną rolę w formułowaniu tez i hipotez filozoficznych. Mogą one prowadzić do skorygowania niektórych koncepcji pytań filozoficznych, które nie powołują się na żadne dane empiryczne.

\section{Słowa kluczowe}

epistemologia genetyczna, epistemologia, filozofia nauki, tomizm, psychologia rozwojowa

\section{Abstract \\ The Ontogenesis of the Question “why," Considered from the Perspective of Genetic Epistemology, and its Philosophical Implications}

The question "why" is generally thought to be one of the most important of philosophical questions. Indeed, many philosophers hold that it is responsible for defining the essential contours and identity of philosophical discourse itself. Moreover, all attempts to reject it are perceived as a manifestation of minimalist tendencies in philosophical research. This article presents Piaget's views concerning the ontogenesis of the "why" question. After having reconstructed the latter, it seeks to spell out their potential philosophical implications. The author argues that ontogenetic considerations can certainly play a heuristic role in the formulation of philosophical theses and hypotheses, and that they can lead to a correcting of the conceptions we tend to have of certain philosophical questions - namely, ones that do not refer to any empirical data. 
Ontogeneza pytania "dlaczego"...

\section{Keywords}

genetic epistemology, epistemology, philosophy of science, Thomism, developmental psychology 